\title{
MAPPING AND NARRATING PHILIPPINE WATERS: EMPIRE AND SCIENCE IN THE ALBATROSS EXPEDITION TO THE US COLONY
}

RUEL V. PAGUNSAN

\section{Abstract}

This paper examines the SS Albatross expedition and the intersection of science and empire in the making of the Philippine maritime environment. In 1907, the United States Government sent its seasoned scientific ship to explore and study Philippine waters and marine resources. For about three years, the Albatross facilitated the mapping of the archipelago's seas and the accumulation of an immense number of natural history specimens. The expedition illustrated the shifting metropolitan policy to re-delegate America's 'duty' to its new colony from military personnel to federal scientists. Primarily using the field journal of Paul Bartsch, the Smithsonian Institution's representative on the expedition, this article interrogates various aspects of knowledge making, from the essential role of Filipino collectors to the eventual publication of research on the accumulated species. I argue that the most significant outcome of the Albatross expedition was the transfer of specimens to the metropole, creating and fortifying the United States as an empire of information in the early twentieth century.

Keywords: Philippines, SS Albatross, United States, imperial science, natural history collecting, knowledge production

\section{Introduction}

In 1907, the Bureau of Science in Manila, under the American colonial government, recommended a comprehensive examination of Philippine territorial waters and adjacent seas. The bureau, however, was 'handicapped by the lack of proper facilities', particularly of navigational equipment needed in traversing the archipelago's high seas. ${ }^{1}$ The Governor-General, William Cameron Forbes, upon the suggestion of the bureau's ichthyologist Alvin Seale and Interior Secretary Dean Worcester, requested

1 Paul Freer, Seventh annual report of the Director of the Bureau of Science to the Honorable the Secretary of Interior for the year ending August 1, 1908 (Manila: Bureau of Printing, 1908), 26. 
President Theodore Roosevelt to send the SS Albatross to the Philippines to facilitate the survey and collection of marine specimens in the archipelago and nearby territories. ${ }^{2}$ In return, the Philippine Government would supply coal throughout the duration of the steamer's operations in Philippine waters. Manila would also serve as the base of the expedition. In September 1907, Roosevelt 'authorized and directed the assignment of the Albatross' for a scientific expedition to the newly acquired colony. ${ }^{3}$

In the decade following its takeover of the Philippines in 1898, the United States Government embarked on various explorations and investigations in attempts to understand its new colony. The occupying US Army was tasked not only with reinforcing political stability in various provinces, but also collecting documents, artefacts, specimens and information necessary for colonial administration. The Bureau of Science was established in 1901 to institutionalise the collection of the archipelago's natural history specimens. This paper looks at the scientific explorations in the Philippines in a period marked by what scholars describe as America's 'renewal of frontier mentality', powered by its 'imperial adventure.. ${ }^{4}$ The archipelago's waters remained mare incognitum until this time.

The Albatross expedition to the Philippines, which lasted about three years, was likely the only scientific exploration the US Government sent to the colony. Federal scientific institutions, particularly the Smithsonian Institution, relied on personnel already stationed in the colony for the collection of specimens and artefacts. In the early years of the US colonial regime, the Smithsonian depended heavily on American soldiers, tasking them to report and collect any species deemed new or interesting to science. ${ }^{5}$ Later, when the scientific operations in the colony had been fully institutionalised, the US National Museum ${ }^{6}$ began to rely instead on Bureau of Science personnel for the regular supply of natural history materials. ${ }^{7}$

\footnotetext{
2 Alvin Seale, Quest for the golden cloak, and other experiences of a field naturalist (Stanford, CA: Stanford University Press, 1946), 95.

3 Hugh M. Smith, 'The "Albatross" Philippine Expedition', in 'Papers on collections gathered by the Philippine "Albatross" Expedition, Contributions to the biology of the Philippine Archipelago and adjacent regions', U.S. National Bulletin 1001 (Washington, DC: US Government Printing Office, 1928), iii.

4 Donald Pease, 'New perspectives on U.S. culture and imperialism', in Cultures of United States imperialism, ed. Amy Kaplan and Donald Pease (Durham, NC, and London: Duke University Press, 1993), 31.

5 On the role of American soldiers in imperial collecting, see Cheryl Beredo, Import of the archive: U.S. colonial rule of the Philippines and the making of American archival history (Sacramento, CA: Litwin Books, 2013).

6 The Smithsonian Institution, the National Museum of the US Government, was established in 1846. It administers the federal museums and research centres, including the National Museum of Natural History where most of the Philippine specimens collected during the Albatross expedition are stored. For a history of the Smithsonian museums and collections, see William Walker, A living exhibition: The Smithsonian and the transformation of the universal museum (Amherst, MD, and Boston, MA: University of Massachusetts Press, 2013).

7 For discussion on the Bureau of Science, see Rodney Sullivan, Exemplar of Americanism: The Philippine career of Dean C. Worcester (Ann Arbor, MI: Center for South and Southeast Asian Studies, University of Michigan, 1991), 115-18; Warwick Anderson, Colonial pathologies: American tropical medicine, race and hygiene in the Philippines (Durham, NC: Duke University Press, 2006), 111-13.
} 
The results of the Albatross expedition were expected to assist the colonial government in instituting policies and programs deemed crucial in revitalising and modernising the fisheries industry of the colony. Hence, the Albatross expedition not only collected scientific data on the archipelago's marine environment, but also the water knowledge and practices of the natives associated with their fisheries and water traditions. This paper examines how the expedition mapped the archipelago's waters as well as how it narrated the maritime traditions of the Filipinos. In particular, it interrogates the expedition diary of Paul Bartsch, one of the scientists who joined the expedition. Bartsch, a zoologist at the Smithsonian Institution, left an elaborate journal of the Albatross' activities from the day of the steamer's arrival in Manila in November 1907 until his early departure in August $1908 .{ }^{8}$

\section{Imperial collecting and colonial knowledge}

Scientific exploration was essential for knowledge gathering, especially for empires that relied on intensive data for colonial authority and control. Scholars, particularly Bernard Cohn, have demonstrated the profound connections between the discourses of scientific knowledge and the ideologies of colonialism. ${ }^{9}$ Their influential works have offered new ways for historians to interrogate colonialism as essentially a mechanism of accumulating and constructing knowledge. In Colonialism and its Forms of Knowledge, Cohn argues that colonial conquest was concomitantly an invasion of the territory's 'epistemological space'. By conquering the episteme of a colony, colonialism produced 'a series of facts' in which the colonised people and their environment 'could be known and represented'. These facts, gathered through predefined, Eurocentric methods called 'investigative modalities' were codified and interpreted in various forms as, among others, dictionaries, legal codes and natural histories. As mountains and seas were surveyed and mapped, plant and animal species listed and ethnic groups accounted for, natural history helped create an 'empire united by information.. ${ }^{10}$ The Albatross scientific expedition-aimed at conquering Philippine waters and obtaining what was believed to be new and significant knowledge-represented Cohn's 'survey modality', one of the six 'investigative modalities' essential to imposing imperial dominance on a colonial territory. ${ }^{11}$ These

8 Paul Bartsch served the Smithsonian Institution for 50 years (1896-1946). With a PhD from the University of Iowa, Bartsch's zoological interests were in malacology and later expanded to ornithology. Besides his duties at the Division of Mollusks of the US National Museum of Natural History, where he was curator from 1913 until his retirement in 1946, he also taught at George Washington University. After the Philippine explorations, he joined expeditions to Cuba, Puerto Rico and the West Indies. More of his biographical profile is at the Smithsonian Institution Archives website: siarchives.si.edu/collections/siris_arc_217247, accessed 21 July 2017.

9 Bernard Cohn, Colonialism and its forms of knowledge: The British in India (Princeton, NJ: Princeton University Press, 1996).

10 Thomas Richards, Imperial archives: Knowledge and fantasy of empire (London: Verso, 1993), 1.

11 The other modalities are historiographic, observational/travel, enumerative, museological and surveillance: Cohn, Colonialism and its forms of knowledge, 3-15. 
modalities framed and reduced the colony and its people into various operative 'codes' that served the purposes of the colonial regime. For Cohn and other scholars, epistemological conquest was the key to imperial power. ${ }^{12}$

US colonialism fuelled intensive and extensive knowledge-making investigations about the Philippines. The historian Alfred McCoy characterises the American empire as a regime of information that 'amassed contemporary data for control from without'. ${ }^{13}$ In the first decade of their rule, American imperial officials pursued 'hasty, inherently superficial surveys of the Philippine present through cadastral mapping, census taking, geography, photography, police surveillance, and scientific reconnaissance'. What emerged, according to McCoy, was an 'American innovation' in imperial knowledge-production that advocated research for pragmatic applications. ${ }^{14}$

America's epistemological construction of the Philippines commenced simultaneously with the US Army's pacification of the archipelago. The historian Reynaldo Ileto astutely argues that the early American knowledge-gathering activities in the colony were closely embedded in military operations. ${ }^{15}$ The Philippine-American War that broke out in February 1899 took US forces to various parts of the country, allowing them to collect all sorts of information, artefacts and specimens. Alongside the campaigns to quell the Filipino resistance movement, American soldiers carried out different techniques of knowing such as surveillance, census taking and sanitation works. ${ }^{16}$ The war, as Ileto conveys, 'was, in a sense, all about filling in that vast knowledge gap'. ${ }^{17}$

The White House understood the importance of scientific collecting to fully grasp the colony's natural environment. Just months after bestowing on Filipino revolutionaries a general pardon that unilaterally declared an official end to the Philippine-American War in 1902, Roosevelt proposed a scientific survey of the Philippines. ${ }^{18}$ In doing so, he signalled the realignment of America's Philippine

12 Cohn, Colonialism and its forms of knowledge, 3-15; Richards, Imperial archives.

13 Alfred McCoy, Policing America's empire: The United States, the Philippines and the rise of the surveillance state (Madison, WI: University of Wisconsin Press, 2009), 44.

14 McCoy, Policing America's empire, 44.

15 Reynaldo Ileto, 'Knowledge and pacification: The Philippine-American War', in Knowing America's colony: A hundred years from the Philippine War (Philippine Studies Occasional Papers Series, 13) (Manoa: Center for Philippine Studies, University of Hawai i at Manoa, 1999).

16 For additional discussion on the role of the US Army in the American census and sanitation projects in the Philippines, see Anderson, Colonial pathologies; and Vicente Rafael, 'White love: Surveillance and nationalist resistance in the U.S. colonization of the Philippines', in Cultures of United States imperialism, ed. Kaplan and Pease, $185-218$.

17 Ileto, 'Knowledge and pacification', 28.

18 In July 1902, Roosevelt issued a general amnesty to all Filipinos involved in the Philippine-American War following the capitulation in April 1902 of Miguel Malvar, the 'last' Filipino revolutionary general to surrender to the American government. Theodore Roosevelt, 'Amnesty Proclamation, July 4 1902', in William Cameron Forbes, The Philippine Islands (Boston, MA, and New York: Houghton Mifflin, 1928), 2: 449-50, Appendix X. 
'duty' from the military personnel to the federal scientists. On 26 December 1902, Roosevelt wrote to the National Academy of Sciences on 'planning a comprehensive investigation of the natural resources and natural history of the islands. ${ }^{19}$ He expressed his opinion that the Philippines possessed 'many interesting and novel questions with respect to [its] ethnology, flora and fauna, and geology and mineral resources', which, if explored and documented, would be of significant value to the 'world'. ${ }^{20}$ A committee was immediately created, headed by the Yale University botanist William H. Brewer, to formulate a plan. The committee recommended a 'scientific exploration' of the archipelago as a prerequisite to any work on promoting the 'commercial and industrial welfare of the inhabitants'. For the committee, US scientific research on the Philippines was both an extension of, and contribution to, Western civilisation:

Since the United States is engaged in the first serious attempt to develop an AngloSaxon civilisation in the Tropics and among a non-Aryan people, it may not be amiss to call attention to the effect on enlightenment and culture of the Filipinos which systematically undertaken scientific surveys must inevitably produce. Such explorations will be practical lesson in the application and value of learning. ${ }^{21}$

To carry out the work, the committee formed in February 1903 the Washingtonbased Board of Scientific Survey of the Philippine Islands, with the US Geological Survey chief Charles D. Walcott as its chair. The other members included the heads of other federal scientific bureaus. ${ }^{22}$ The project also called for the participation of the US Army and Navy, which would provide supplies and security, and assist in the transport of personnel and specimens. All specimens collected would be handed to the Smithsonian. The board listed the fields for investigation over the following decade, prioritising research on: 1) coastal and geodetic work, and marine hydrography; 2) topography; 3) geology; 4) botany; 5) systematic forestry; 6) zoology; and 7) anthropology. In zoological investigations, in particular, the committee was instructed:

Special attention should be paid to the fishes. A careful study should be made of their distribution, abundance, spawning habits, food, and enemies, and of all other questions that would aid the Philippine government in protecting the fisheries resources of the islands and in extending their utilization. ${ }^{23}$

19 National Academy of Sciences, Scientific Exploration of the Philippines Islands, 58th Congress, 3rd session, Senate Document 145.

20 National Academy of Sciences, Scientific Exploration of the Philippines Islands.

21 National Academy of Sciences, Scientific Exploration of the Philippines Islands.

22 The Board was composed of the superintendent of the US Coast and Geodetic Survey, the chief of the US Biological Survey, a botanist from the US Department of Agriculture, the chief of the Bureau of Forestry, the chief of the scientific staff of the Fish Commission and the chief of the Bureau of American Ethnology.

23 National Academy of Sciences, Scientific Exploration of the Philippines Islands. 
In June 1903, the board readied the proposal for legislative enactment. The US Congress and Senate, however, were wary of the proposal, possibly because of the huge expense it would entail and the duplication of work with American scientists in the Philippines. ${ }^{24}$ After two years, Roosevelt sent a special request to the senators and congressmen to act favourably on the proposal, which he considered 'a national duty in the interest of science'. ${ }^{25}$ Despite White House intervention, the legislators did not take any action. ${ }^{26}$ Nonetheless, the project illustrated how Roosevelt envisaged the US empire in the Philippines. The President stressed that the scientific survey was not only a responsibility in line with the circumstantial 'control' of the Philippines, but also 'a matter of pride to the government of the United States'. By positioning the Philippine scientific survey as an element of American 'national' duty and pride, Roosevelt was set to develop America's imperial engagement in the archipelago.

Roosevelt's desire to explore the colony's natural world reflected the metropolitan impulse of the time about the promise of the Philippines. Institutions such as museums and universities optimised what they deemed opportunities to explore the new frontier. For instance, the New York Botanical Garden dispatched Robert Statham Williams for extensive plant collecting in Luzon from 1903 to 1905, and the Field Museum in Chicago, through its benefactor Robert F. Cummings, sent anthropologists such as Fay-Cooper Cole for ethnographic collection between 1907 and 1910. ${ }^{27}$ These metropolitan-based explorations not only accumulated specimens, but also images, observations and all sorts of information intended to satiate imperial curiosity. The art historian David Brody argues that the materials and knowledge generated by such colonial collecting 'furthered empire while concomitantly fostering a space where debates about the empire could take place'. ${ }^{28}$

24 Officials in Manila were made aware of the Roosevelt plan. While they welcomed the proposal, they were also anxious that they would be relegated to the sidelines. The Philippine colonial government insisted that the metropole-led scientific expeditions should be conducted side by side with the colonial staff, arguing that 'a candid and frank recognition of the merits of the work both in Washington and in the Philippine Islands will be the only method by which the best results can be obtained'. They insisted that the scientists in Manila and Washington should collaborate, especially in pursuing 'similar lines of work', and that 'separation of the two would only result [in] disadvantage to both'. Paul Freer, Second report of the Superintendent of the Government Laboratories of the Philippine Islands for the year ended September 1, 1903 (Washington, DC: War Department Bureau of Insular Affairs, 1903), 361.

25 'Message from the President of the United States to the Senate and House of Representatives, 7 February 1905 ', in National Academy of Sciences, Scientific Exploration of the Philippines Islands.

26 Rexmond Cochrane, The National Academy of Sciences: First Hundred Years, 1863-1963 (Washington, DC: National Academy of Science, 1978), 174.

27 Edwin Copeland, 'Philippine ferns collected by R.S. Williams', Britonnia 1 (October 1931): 67-70; Bennet Bronson, 'The Field Museum and the Philippines', Field Museum of Natural History Bulletin 53, no. 7 (July-August 1982): 4-33.

28 David Brody, Visualizing American empire: Orientalism and imperialism in the Philippines (Chicago: Chicago University Press, 2010), 2. 
The Albatross expedition brought to the United States natural history specimens and information that 'represented' the Philippines in various arenas such as journals, bulletins, aquaria and museums. ${ }^{29}$

\section{The Albatross as a scientific instrument}

In a pivotal article that re-evaluates the role of ships during the era of scientific explorations and discoveries, the historian Richard Sorrenson argues that some vessels operated not just as 'a vehicle that transported investigators', but also as an 'instrument' capable of generating information for science. ${ }^{30}$ In particular, he examines the British and French vessels in the eighteenth century designed primarily for exploration. Aside from modern instruments capable of surveying and mapping 'new' territories, scientific vessels also carried naturalists, astronomers and illustrators, providing these personnel a 'platform' to personally observe the field. Hence, scientific ships became important sites of knowledge-making, as 'they shaped the kinds of information the observers collected'. ${ }^{31}$ Building on Sorrenson's work, the historian Anthony Adler interrogates the evolving and expanding uses of expedition ships, emphasising their function as a laboratory space where the technical crew performed their initial assessment, experiments and other scientific work. ${ }^{32}$ 'Changes in research vessel usage accrued gradually over time', Adler explains, 'and earlier usages persist alongside later innovations' ${ }^{33}$ The Albatross was an instrument, observatory and laboratory ship that modernised research on oceanography and advanced studies on ichthyology and fisheries in the Philippines. ${ }^{34}$

Built in 1882 for the US Fish Commission (renamed the Bureau of Fisheries in 1903, and now the National Marine Fisheries Service), the Albatross was the first of its kind designed primarily for oceanographic research. It was fitted with advanced dredging engines that could power the steamer to scoop specimens from the bottoms of the sea at ' 4,500 fathoms' $(8.3 \mathrm{~km})$. It had various sizes of bottom

\footnotetext{
29 Paul Kramer has examined the American Empire's representation of the Philippines in the St Louis Exposition in 1904, see Chapter 4 of The Blood of Government: Race, Empire, the United States, \& the Philippines (Chapel Hill, NC: University of North Carolina Press, 2006).

30 Richard Sorrenson, 'The ship as scientific instrument in the eighteenth century', Osiris 11 (1996): 222.

31 Sorrenson, 'The ship as scientific instrument', 227.

32 Anthony Adler, 'The ship as laboratory: Making space for science at sea', Journal of the History of Biology 47 (2014), doi.org/10.1007/s10739-013-9367-7.

33 Adler, 'The ship as laboratory', 358.

34 The Albatross' contributions in the sciences were intimately linked with the scientists associated with the steamer. For instance, see Larry T. Spencer, 'Four men and an Albatross: The growth of American oceanography, 1882-1921', in Oceanographic history: The Pacific and beyond, ed. Keith Benson and Philip Rehbock (Seattle, WA: University of Washington Press, 2002), 288-97.
} 
trawls: the most frequently used in the expedition was the 12-foot $(3.7 \mathrm{~m})$ Agassiz beam trawl. Seines, plankton nets, dip nets and all other forms of nets and traps were used whenever the ship was at anchor or the team was collecting along shores. ${ }^{35}$

The Albatross was also the first US government vessel to be supplied with electric lighting, allowing the scientists to work at night. Adler explains how the electrical technology revolutionised oceanographic research:

Electric lightning served as a lure for marine creatures. By extending working hours and permitting scientists to gather specimens at night, electricity amplified the research vessel's extension of scientists' reach in time as well as in space. ${ }^{36}$

Bartsch's journal indicates countless instances when the Albatross crew performed their collecting works at night, sometimes extending beyond midnight. ${ }^{37}$

The steamer was provided with a huge amount of space in which the personnel could store the collections. It had a spacious laboratory where the naturalists on board performed all the necessary work to preserve and identify the specimens before they were packed for shipment to the United States. It also had a wide berth deck, which functioned as the second laboratory. The naturalist Roy Chapman Andrews, who joined the expedition in 1909, described the Albatross in his memoirs as 'the most famous ship of her kind. No other exploring vessel was so well equipped for deep sea dredging ... She was a beautiful ship, built like a yacht, with a wide after-deck where the officers slept on camp beds when the night was hot'. ${ }^{38}$

During its four decades of service, the Albatross made important scientific surveys along various coasts of the mainland United States, Alaska, and Hawai'i. Prior to its surveys of the Philippines, it undertook an expedition in 1904-05. Headed by Alexander Agassiz, the steamer plied the Pacific seas and made collecting surveys in areas such as the Galapagos, Easter Island and Callao. ${ }^{39}$ According to Bartsch, 'among the many cruises made during her [Albatross'] long career, none has yielded greater scientific results than her work in the waters of the Philippines and adjacent seas'. ${ }^{40}$

35 For a discussion on the beginnings of the Albatross, as well as the steamer's features, see Dean Allard, 'The origins and early history of the steamer Albatross, 1Ą7', Marine Fisheries Review 61, no. 4 (1999): 1-21.

36 Adler, 'The ship as laboratory', 351-2.

37 For instance, Bartsch wrote on 5 December 1907: 'Tried to catch some of the small fish but they all went through. Mr Seale came aboard at 6PM and visited until 10. After this Dr Smith and I tried different net and electric light from the gangplank. He held the light and I caught a small fish.' 'Notes on the Philippine Expedition, Book No 1'. RU 7089. Smithsonian Institution Archives, Washington, DC.

38 Roy Chapman Andrews, Under a lucky star: A lifetime of adventure (New York: Blue Ribbon Books, 1945), 50, 66.

39 Alexander Agassiz, General Report of the Expedition ([s.l.]: Harvard Museum of Comparative Zoology, 1906). 40 Paul Bartsch, 'Dr. Hugh M. Smith, Director of the Philippine Cruise of the "Albatross"', Copeia (November 1941): 209. 


\section{The Albatross in the Philippines}

The Albatross was under the jurisdiction of the US Bureau of Fisheries, but was operated and manned by the US Navy. This arrangement was clear in the Philippine expedition. ${ }^{41}$ Commander Marbury Johnston (September 1907 - June 1908), and later Commander C. W. McCormick (June 1908 - May 1910), captained the cruise while US Fisheries Deputy Commissioner Dr Hugh M. Smith was appointed director of the expedition. Aside from Smith, the 'scientific force' also consisted of Frederick Chamberlain (resident naturalist), Lewis Radcliffe (naturalist and general assistant), H. C. Fassett (fisheries expert), Clarence Wells (clerk) and Dr Paul Bartsch (zoologist), who represented the Smithsonian Institution. ${ }^{42}$ They were joined by the Japanese artist Kumataro Ito, who was hired to render illustrations of specimens. ${ }^{43}$ The zoology students Albert Barrows and Roy Chapman Andrews joined for the second half of the explorations. ${ }^{44}$ Seale, representing the Philippine Government, was present on the first voyage to Mindanao, but thereafter joined the expedition only intermittently. ${ }^{45}$

The Albatross left San Francisco on 16 October 1907. After a stopover at Honolulu, the Marshall Islands and Guam, the Albatross reached Manila late in the morning of 28 November. The next day, Bartsch and other members visited the Bureau of Science and met with its resident technical staff. ${ }^{46}$ The Albatross did not immediately embark on a major voyage as the team waited for Director Smith and Ito, who arrived later from Japan, and for the equipment which arrived from the United States in about January $1908 .{ }^{47}$ For the next two months, the team was mainly stationed in Manila, but nevertheless managed to undertake collecting in the city's suburbs and nearby provinces. They visited the districts along the coasts of the capital and the major rivers connected to Manila Bay. Bartsch also made collecting trips to several towns in Laguna, Batangas and Zambales. He toured the coastal towns surrounding Laguna Lake and visited beaches and popular natural landmarks, such as the Botocan Falls and Taal Lake. ${ }^{48}$

\footnotetext{
41 The relationship of naval officers with the scientific crew was often characterised by tension. Andrews wrote about this 'friction' in his published diary, which perhaps explained the departure of some staff at the midpoint of the exploration. See Andrews, Under a lucky star, 67.

42 Andrews, Under a lucky star, 67.

43 Victor Springer, 'Kumataro Ito, the Japanese artist on board the U.S. Bureau of Fisheries steamer Albatross during the Philippine expedition, 1907-1910', Marine Fisheries Review 61, no. 4 (1999): 42-57.

44 David G. Smith and Jeffry T. Williams, 'The Great Albatross Philippine Expedition and its fishes', Marine Fisheries Review 61, no. 4 (1999): 34.

45 Seale was the assistant scientific investigator at the US Bureau of Fisheries when Roosevelt appointed him in 1907 to head the Ichthyology Section of the Bureau of Science. A Stanford graduate, Seale stayed in the Philippines until 1917. One of his notable works in the colony was the establishment of the Manila Aquarium. In his published memoir, Quest for the golden cloak (1946), he devoted one chapter on his experiences in the Philippines.

46 Paul Bartsch, 'Notes on the Philippine Expedition of the Steamer Albatross, Book No. 1'.

47 Smith and Williams, 'The Great Albatross Philippine Expedition', 33.

48 Bartsch, 'Dr. Hugh M. Smith', 215.
} 
The first major voyage of the Albatross in the Philippines departed in early February 1908. From Manila, the ship cruised to the western coasts of Mindanao, Tawi-tawi, the Sulu Archipelago (including the Siasi Island and Sibutu Island) and extended its voyage to Sandakan in Borneo (now Sabah, Malaysia). Before heading back to Manila, the expedition travelled to the coasts of Luzon, visiting Baguio, Trinidad, Naguilian, Dagupan and Cavite. The second leg of the expedition targeted the central part of the archipelago. From mid-March to late April, the Albatross traversed the waters of Tablas, Panay, Negros, Cebu, Bohol, Leyte, Samar, Marinduque and Masbate. The expedition returned to the Visayas and Mindanao for the third leg. From May to June, the dredging and collecting activities concentrated in Mindoro, and south-eastern and eastern Mindanao. When the vessel returned to Manila on 9 June, further operations had to be suspended because of the steamer's battered condition - the Albatross was eventually brought to Hong Kong for complete restoration. At this time, three of the original members had already left the team. Smith withdrew after the second voyage in April, and Radcliffe and Bartsch left after the third. Seale was said to represent the Smithsonian after Bartsch's departure. ${ }^{49}$

After repairs were completed in October 1908, the Albatross resumed collecting on its way back to Manila through the Batanes and Babuyan Islands and the northern coast of Luzon. Thereafter, six more voyages were undertaken. From December 1908 to January 1909, the expedition was directed at the Calamianes group of islands, western and southern Palawan, and southern and western Panay. Between February and April 1909, the expedition covered the coasts of southern Luzon, and rounded the small islands in the Bikol region, Bohol, eastern Palawan and Cuyo Island. In early May, five days of collecting were devoted to the coasts of Bataan and Zambales. In late May to June, the Albatross returned to southern Luzon and extended the expedition to Samar and Leyte. From July to October, the exploration targeted the northern coasts of Mindanao; this voyage 'completed the survey of the Philippine proper'. ${ }^{50}$ Before it returned to the United States, the Albatross undertook its final expedition, to the waters of the Dutch East Indies.

Dynamiting was among the collection methods employed on the Albatross. This involved the use of small explosives with electrical charges to obtain specimens from the desired reefs or other sites. Bartsch explained that the use of dynamite particularly targeted the 'coral reef dwellers [which] are so securely tucked away among the crevices that no dredge or other implement could possibly coax them forth'. ${ }^{51}$ Dynamiting could be undertaken in a series of explosions at a single location. In one dynamiting action in Puerto Galera, Mindoro (the future site of the Philippine Marine Laboratory Station), on 9 June 1908, Chamberlain conducted several rounds of dynamiting at 6.00-7.20 am and then at 8.30-11.30 am. Bartsch

49 Smith, 'The "Albatross" Philippine Expedition', iii-iv; Smith and Williams, 'The Great Albatross Philippine Expedition', 34-5.

50 Smith and Williams, 'The Great Albatross Philippine Expedition', 35.

51 Bartsch, 'Dr. Hugh M. Smith', 214. 
reported that the party amassed 124 species from 27 kinds of marine animals. ${ }^{52}$ Although dynamiting presented some hurdles (especially when winds and tides made it difficult for collectors to gather the dynamited species), nonetheless, it proved to be the easiest method for accumulating marine specimens.

Shore and land collecting was conducted whenever the steamer was at anchor. Bartsch recorded every bay and point where the Albatross stopped. While the ship was dredging, hauling or coaling, Bartsch would go ashore and explore a river to the point where the boat could pass. If the steamer stayed longer, he would go further into the headwaters, explore the forests or climb the mountains. During his oneyear cruise, Bartsch explored the islands of Tayabas, Romblon, Iloilo, Cebu, Bohol, Tacloban, Catbalogan, Ticao, Burias, Surigao, Jolo, Davao, Lanao, Cotabato, Guimaras, Mindoro, Marinduque and Palawan. The Smithsonian representative also took time to visit the areas where earlier naturalists had undertaken their explorations. He visited Marikina where Paul Georg von Mollendorf had investigated the local molluscs that, Bartsch wrote, became one of the works that 'la[id] the foundation' for the studies on the 'Philippine fauna later'. ${ }^{53}$ Bartsch also tried to follow the expedition trail of Major Edgar Mearns in Mindanao, particularly in Lake Lanao where the US Army major had discovered viviparous animals:

How I wish I might have a week more here. It seems hard to leave the place which I have longed to explore ever since Dr Mearns brought back the vivaparous. I have had just enough time to see that there is much more work here and must be continued to know the place. ${ }^{54}$

Bartsch's journal reveals the work that each expedition member undertook. Specific assignments allowed the personnel to maximise their time for collecting as the navigator rarely decided to stay at any place beyond a day or two. The Smithsonian representative was responsible for land collecting while Wells, Radcliffe and Chamberlain took turns in dynamiting or dredging. Smith, in most instances, headed the seining activities during his brief directorship of the Albatross. A journal entry on 4 February 1908 while the Albatross was anchored at Nogas Island (south of Panay) showed the division of labour:

After breakfast three parties were dispatched to various parts of the shore for collecting. Merrs. Chamberlain, Radcliffe and a man went to the nearby point dynamiting. I with another [assistant] went to the shore with their boat to collect along the rock bound shores. Dr Smith was charged [with] the seining party on the sandy beach to the south..$^{55}$

52 Paul Bartsch, 'Notes on the Philippine Expedition, Book No. 3'. RU 7089. Smithsonian Institution Archives, Washington, DC.

53 Paul Bartsch, 'Notes on the Philippine Expedition, Book No. 2'. RU 7089. Smithsonian Institution Archives, Washington, DC.

54 Bartsch, 'Notes on the Philippine Expedition, Book No. 2'.

55 Bartsch, 'Notes on the Philippine Expedition, Book No. 2'. 
There were certainly many instances in which the members shared work. In several instances, Batrsch joined one of the parties. The other naturalists usually accompanied Bartsch, especially in exploring the interiors. Radcliffe often went to the markets to survey and purchase fish and shells while Fassett was detailed to secure information from the natives, including 'descriptions and photographs of equipments ranging from fish hooks to mazes of traps ${ }^{5}{ }^{56}$ Bartsch observed the seining and dynamiting works, but did not facilitate them himself.

\section{The Filipinos and the scientific collecting}

Filipino assistants provided essential support to the collecting work. Scholars have highlighted the essential role of natives in natural history expeditions. ${ }^{57}$ In Bartsch's published account of his Philippine experience, the role of the natives was never mentioned. In his logbook, however, he often requested 'Philippinos' on board to accompany him whenever he trekked the shores. It was not mentioned how many locals served in the Albatross, but Bartsch named six of them: Dino, Colleto, Pedro, Maximo, Emilio and Jesus. Bartsch took different assistants, at least two of them, every time he conducted land collecting while the rest helped in seining and dynamiting. In an unpublished manuscript, Bartsch described how Filipinos assisted him in daily routine:

Out to sea at 8 A.M. dredging, returning to some anchorage by 4 P.M.

On reaching an anchorage in the evening I was given a boat with four Philippinos as oarsmen (outboard motors were not then known), and we would run ashore, usually up some river, stopping at intervals to collect shore material. We would return [in the] dark and enjoy a waiting supper.

If material dredged during the day had not been taken completely care of that was next attended to.

If a trial with a submarine lamp showed prospects, plankton fishing was engaged in which sometimes lasted the night through.

Next morning before daylight an orderly, at my request, would rouse me from my slumbers, telling me that my coffee and handout was ready, as was my skiff and four fresh Philippino boys to make another shore try. ${ }^{58}$

56 Bartsch, 'Dr. Hugh M. Smith', 215.

57 For instance, see Fa-ti Fan, British naturalists in Qing China: Science, empire and cultural encounter (Cambridge,

MA: Harvard University Press, 2004).

58 Bartsch, 'Notes on the Philippine Expedition, Book No. 2'. 
In a prolonged inland survey, the party hired more locals to help as rowers, carriers and interpreters. Bartsch mentioned a certain Miguel Bonifacio, possibly a Tagalog, who served as the group's interpreter throughout their exploration of Laguna and Tayabas. It was not clear if these assistants were already present when the expedition started, although Bartsch suggested that there were 'men' helping them on board when the major voyage commenced on 1 February 1908. Unfortunately, Bartsch's early departure meant there were no further entries in the logbook, which might have provided further documentation on the role of native assistants during the remainder of the expedition. When Andrews joined the Albatross in 1909, he was assigned the role of a land collector. ${ }^{59}$ Andrews indicated that he was aided by local guides, and identified one of them as Mirando.

The entire expedition, Bartsch noted, had provided the crew with 'a wonderful contact with the Philippine life'. ${ }^{60}$ Bartsch's journal contained not just dredging records, map sketches and collected materials, but also commentaries on many aspects of the islands and its people. The Smithsonian agent took time to compose his observations on topics ranging from the physical appearance of the natives and their dwellings, to countryside scenes, local industries, church ceremonies and street and transport conditions. The period the Albatross spent in the Philippines coincided with the growing assertion of the imperial authority of the United States. Bartsch's daily account affords us a glimpse of the range and reach of colonial state-building. In Benguet, Bartsch lauded the Bureau of Agriculture for 'making ground work' by means of the Agricultural Crop Station. In Laguna, he praised the 'excellent condition of roads' and the ongoing bridge construction being undertaken by Bilibid prisoners. He noticed the growing presence of Americans in the provinces, especially educators, and he was impressed by the English literacy of young Filipinos. He mentioned the Americans were entering into the lumber, pearl, transport and other industries. In Mindanao, he spoke of the ongoing Moro War and of the triumphs of Generals Leonard Wood and John Pershing.

But, among many things, Bartsch was especially riveted by the archipelago's maritime and fishing culture. ${ }^{61}$ On the day the Albatross first arrived in Manila Bay, he immediately noticed 'the numerous native crafts [sic] of various kinds that plied about us'. ${ }^{62}$ He visited coastal communities including Tondo, the nearest 'chief fishing place' to the capital, with its 'hundreds of bancas ... with their own crew of fishermen'. ${ }^{63}$ His journal furnishes details of local collecting methods, sketches of native fishing tools and vernacular names of collected specimens. From

59 Andrews, Under a lucky star, 72.

60 Bartsch, 'Dr. Hugh M. Smith', 212.

61 Besides collecting specimens, scientists in the field also gathered local knowledge. For an examination of the reliance of marine scientists on local data, see Chapter 2 of Samantha Muka, 'Working at water's edge: Life sciences at American marine stations, 1880-1930' (PhD diss., University of Pennsylvania, 2014), 83-118.

62 Bartsch, 'Notes on the Philippine Expedition, Book No. 1', 28 November 1907.

63 Bartsch, 'Notes on the Philippine Expedition, Book No. 2', 31 December 1907. 
the pearl divers in Lanao to the fishermen in Laguna de Bay, he chronicled the travails of the people involved in the local industries. He observed fishponds and markets, smoked fish makers and fishing-net manufacturers, and bangus (milk fish) cultivators and duck-raisers. Batsch looked at the many aspects of the fisheries' conditions in the colony, from a small pond in San Mateo where locals underwent 'a laborious process which apparently yield[s] but scant results', to the large-scale fishing industry in Laguna de Bay, where he witnessed fishermen constantly on the move as they inspected 'hundreds upon hundreds of fish nets' scattered around the bay. ${ }^{64}$ On a beach in Bacoor, Cavite, where fishermen landed their catch for the buyers, he noted that 'fish are sold for two pesos a hundred'. ${ }^{65}$ The fishing industry in Lake Taal and Pansipit River generated a revenue of 6,500 pesos every year for a concession granted 'annually to the highest bidder' ${ }^{66}$

The expedition benefited from the natives who performed a variety of tasks as guides, interpreters, carriers, trackers and hunters of specimens. The American explorers included the Filipinos as the integral part of the expedition staff. Moreover, the native assistants were important sources of cultural stories that added a 'human' dimension to the scientific narratives, which the Albatross' scientists collected.

\section{Specimens and empire}

Before leaving Manila on 5 August 1908 to return to the United States, the Smithsonian representative met the Bureau of Science Director Paul Freer regarding 'establishing cordial relations between his and our Institution'. ${ }^{67}$ Bartsch deemed it necessary to cultivate these 'cordial relations' after the US Bureau of Fisheries had determined to take full control of the expedition and that fish specimens would be brought to Washington, DC. This decision dismayed officials in Manila, especially Interior Secretary Worcester. The minimal presence of Seale, the Philippine Government representative, during the duration of the Albatross expedition might be explained by this animosity.

The Manila conversation focused on the exchange of specimens: the Smithsonian would turn over some specimens collected by the Albatross, while the Bureau would send to Washington its collections for which there were no specialised Philippine scientists available. Freer also suggested, to which Bartsch fully agreed, that the

64 Bartsch, 'Notes on the Philippine Expedition, Book No. 1', 1 and 16 December 1907.

65 Bartsch, 'Notes on the Philippine Expedition, Book No. 3', 27 June 1908.

66 Bartsch, 'Notes on the Philippine Expedition, Book No. 1', 27 December 1907.

67 Bartsch, 'Notes on the Philippine Expedition, Book No. 3', 5 August 1908. Paul Freer was one of the American officials assigned to the Philippines. He led the Bureau of Science from its foundation in 1901 until his death in 1912. Before his colonial service, Freer was professor of chemistry at the University of Michigan. The Bureau issued a special issue of its journal commemorating Freer's life and works: The Philippine Journal of Science 7 (memorial number) (July 1912). 
Bureau could become the collecting agency for the Smithsonian. Worcester, with whom Bartsch also liaised, concurred with the plan. With its own personnel in the field, the bureau could undertake a 'special search' for the Smithsonian 'at a very low cost getting the production and assistance of the local men'. Freer assured Bartsch that the Bureau was the right agency 'for the specimens as shipped from the field until the final packing and shipping to the States'. In other words, the meeting between the Smithsonian agent and the bureau, as Bartsch summarised it, was 'cooperation in every sense of the word' ${ }^{68}$ Indeed, in the years to come, this cooperation would deepen, especially in the exchange of specimens. As there was no subsequent expedition on the scale of the Albatross', the Bureau of Science would later represent the Smithsonian's interests in the Philippines. In the time when the US National Museum was preparing for the publication of the Albatross collections, the Smithsonian would invoke this 'informal understanding', as it needed the Bureau of Science for supplementary specimens. ${ }^{69}$

The bulk of Philippine specimens that the Albatross collected were handed over to the Smithsonian. Bartsch estimated that the Albatross had collected 400,000 fish specimens, although the US National Museum estimated there were only between 100,000 and 150,000 specimens. On its web page, the Smithsonian notes that 'fishes from the Philippines expedition equaled nearly 40 percent of the entire [ichthyology] collection. It was the largest single accession of fishes ever received by the museum'. ${ }^{70}$

The Smithsonian started publishing the results of the Albatross expedition even before the return of the vessel to the United States in 1910. Bartsch was actually working on some papers during the expedition and published a paper on Philippine molluscs in $1907 .{ }^{71}$ From 1910 to 1917, the Proceedings of the United States National Museum published a series of papers entitled 'Scientific Results of the Philippine Cruise of the Fisheries Steamer "Albatross," 1907-1910'. In 1917, the Smithsonian ended the series to begin another called National Museum Bulletin 100. Bulletin 100 was devoted to the 'Contributions to the Biology of the Philippine Archipelago and Adjacent Seas', with Bartsch's research on Philippine land shells as the inaugural article. The Smithsonian sent the other Albatross specimens (e.g. sea squirts, jellyfishes, starfishes and corals) to specialists in various museums and universities, such as the American Museum of Natural History, the Museum of Comparative

68 Bartsch, 'Notes on the Philippine Expedition, Book No. 3', 7 July 1908 and 3 August 1908.

69 Assistant Secretary Richard Rathbun, Letter to Bureau of Science acting Director Alvin Cox, Washington DC, 14 October 1913. RU 192. Smithsonian Institution Archives, Washington, DC.

70 Smithsonian National Museum of Natural History, 'Scientific Expeditions: The Albatross, Collections of the Philippines Expedition', vertebrates.si.edu/fishes/albatross/philippines_collections.html, accessed 27 April 2016.

71 Bartsch, upon the suggestion of the Freer and Worcester, originally intended to publish the manuscript in the Philippine Journal of Science, the flagship organ of the Bureau of Science. 
Zoology, Stanford University, the University of Michigan and Harvard University, among others. The contributions from these institutions formed the subsequent issues of the Bulletin.

The US Bureau of Fisheries, on the other hand, held the majority of the icthyological collections. Between 1911 and 1913, Smith (promoted to Fisheries Bureau commissioner) and Radcliffe (promoted to deputy commissioner) published 12 papers on the various groups of Philippine fish in the Proceedings of the Biological Society of Washington. In 1923, the Bureau of Fisheries turned over the collections to the National Museum. Beginning in 1928, the Smithsonian dedicated the contents of Bulletin 100 to the fish collections that were not previously documented by the Bureau of Fisheries. The last volume of Bulletin 100 was released in 1941.

As the Albatross specimens remained largely within the metropole, federal institutions, the Smithsonian primarily, appropriated the authority as the 'author' of the Philippines' environment. Scientists who did not join the expedition similarly participated in conceptualising and bestowing scientific authority on Philippine nature. Moreover, Filipino maritime culture seems to have been ignored in the scientific publications. While the Albatross scientists, especially Bartsch, were keen to document the traditional knowledge and practices of Philippine fishermen, their publications were chiefly framed within the language of science, enumerating the species with their scientific names, provenance and detailed physical description.

\section{Conclusions}

The Albatross expedition to the Philippines illustrated an imperial effort to create a scientific body of knowledge about the Philippines, especially its maritime environment. It was extensive in scope and duration, and generated thousands of specimens. It supplied the metropole with specimens as well as images and observations that slaked public and academic curiosity. Conducted within the first decade of the American regime in the Philippines, it represented the metropolitan yearning to explore the new US colony as a frontier of 'unknown' scientific specimens.

The Albatross scientific expedition benefited from the colonial apparatus that were already in place before its arrival, as well as from the native assistants who were indispensable to the collecting surveys. In return, the exploration of Philippine waters was important for the colonial government as it generated information essential to the mapping of the colony. Furthermore, this information was vital to the formation of narratives that justified imperial policies aimed at introducing ways of maximising the marine potential of the archipelago. Although the expedition was ultimately meant to provide the Manila Government with pertinent information for the development of industrial fisheries in the Philippines, the collaboration between the metropole and colony for such a purpose was marred with issues arising 
from institutional conflict and overlapping authority. The colonial government felt marginalised, and was compelled to independently pursue its fisheries projects in the colony.

But the collection of specimens and their transfer from the colony to the metropole also illustrated the rise of an empire. In her work on the creation of the US colonial archives in the Philippines, the historian Cheryl Beredo argues that the accumulation and seizure of records were not just the corollary of colonial bureaucracy, but an essential component of an emerging American power. ${ }^{72}$ Just like the archives, repositories of natural history specimens were part of the colonial technologies of record-building and knowledge-making. Following Beredo, I consider the possession and transfer of specimens as an element of the US imperial character that fostered how the Philippine natural world was imagined and scripted at the turn of the twentieth century. Scientific museums, herbariums and universities are enduring remnants of the US empire that continue to impact postcolonial scholarship in the twenty-first century. 
This text is taken from International Review of Environmental History, Volume 4, Issue 1, 2018, edited by James Beattie, published 2018 by ANU Press, The Australian National University, Canberra, Australia.

doi.org/10.22459/IREH.04.01.2018.07 